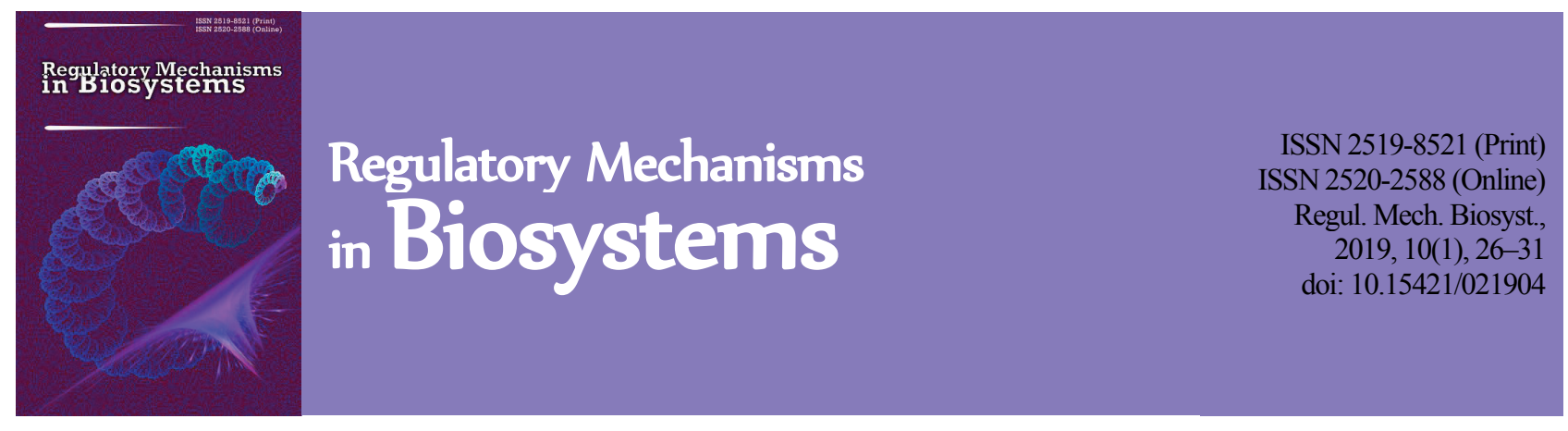

\title{
Clinical-diagnostic criteria and peculiarities of treatment of urocystitis in cats
}

\author{
N. M. Shulzhenko*, O. M. Chernenko*, O. V. Holubyev*, O. G. Bordunova**, N. I. Suslova* \\ *Dnipro State Agrarian and Economic University, Dnipro, Ukraine \\ **Sumy National Agrarian University, Sumy, Ukraine
}

Article info

Received 30.01.2019

Received in revised form 01.03 .2019

Accepted 03.03.2019

Dnipro State Agrarian and Economic University, S. Efremov st., 25 ,

Dnipro, 49600, Ukraine.

Tel.: +38-099-211-10-00.

E-mail:shulzhenko.n@ukr.net

Sumy National

Agrarian University,

H. Kondratiev st., 160 ,

Sumy, 40021, Ukraine.

Tel.: +38-050-407-61-06

E-mail:

bordunova_olga@rambler.ru

\begin{abstract}
Shulzhenko, N. M., Chernenko, O. M., Holubyev, O. V., Bordunova, O. G., \& Suslova, N. I. (2019). Clinical-diagnostic criteria and peculiarities of treatment of urocystitis in cats. Regulatory Mechanisms in Biosystems, 10(1), $26-31$. doi:10.15421/021904
\end{abstract}

The results of a study of cats with signs of urocystitis are presented. The general principles of diagnostics based on clinical, laboratory and additional research methods are established. Clinically acute urocystitis was manifested by disorders of urination pollakiuria, dysuria, stranguria. Some of the animals showed an increase in body temperature, pain in the bladder and tightness of the walls of the abdominal cavity. According to the results of urine study, it was observed that $43.7 \%$ of the cats with urocystitis showed an increase in relative density of the urine, a change in urine $\mathrm{pH}$ towards higher alkaline levels, urine residue erythrocytes, leukocytes and microorganisms were indicated. Impurities of salt and sand were found in $58.4 \%$ of the cats. In $31.4 \%$ of the cats, urocystitis was a complication of urolithiasis. Early diagnosis, especially differential diagnosis of acute and chronic, secondary urocystitis presents difficulties. Therefore, in cases of suspected inflammatory diseases of the urinary tract, a complex examination using ultrasound of the kidneys, bladder, prostate gland (in males) and the uterus (in females) is recommended.With therapeutic purpose, sick cats (two groups of 8 animals/group) were administered: anti-microbial agent (5\% solution of Enrofloxacin), spasmolytic medicinal agent - Riabal ${ }^{\mathbb{B}}$. Animals of the second group were additionally administered the drug Cystocure (Candioli Farmaceutici). According to the instructions, the plant basis of the powder Cystocure is presented by extracts of cranberries and orange peels. These substances provide the main properties of the drug - help in resisting the bacterial colonization of the lower urinary tract and change in urine $\mathrm{pH}$ to the acid side. The applied therapy positively influenced the clinical condition of the cats. Their general health was improved, painful sensations during the act of urination disappeared, the quantity and frequency of diuresis normalized. On the seventh day of treatment, according to the results of the study, the urine became transparent, no microorganisms were detected. In cats of the second group, which additionally used the drug Cystocure, the amount of salts and sand decreased significantly, the $\mathrm{pH}$ of the urine did not exceed the recommended value of 6.4 , in contrast to animals of the first group.

Keywords: urinary tract diseases; ultrasound examination;extracts of cranberries; $\mathrm{pH}$ of urine; Cystocure; blood and urine indexes.

\section{Introduction}

Among the many diseases of small animals, the pathology of the urinary system, in terms of the prevalence and number of fatal cases, takes one of the leading places along with diseases of the cardiovascular system, tumors and traumatic injuries. Various etiological factors that interrupt metabolism and homeostasis and are inadequate for the body, cause the development of pathological process in the urinary system. The first manifestations of pathology are not always possible to diagnose in a timely manner, therefore, there is a probability of increase and complication of the primary pathological process in other organs and systems, in particular, the cardiac, digestive, and nervous systems (Brown et al., 2007; Jepson et al., 2007; Bartges, 2012; O'Neill et al., 2013; Pouchelon et al., 2015). Diagnosis of diseases of the urinary system remains a significant problem in veterinary medicine. Therefore, a skilled study of the urinary tract should be based on the complex application of traditional and modern instrumental research methods (Platt et al., 1990; Grauer, 2005; Kumar et al., 2011; Shulzhenko \& Ryabik, 2017).

Urocystitis is manifested by acute or chronic inflammatory processes in the mucous membrane of the bladder. Sometimes the entire wall of the bladder is involved in the pathological process. It is one of the most common urological diseases with which owners bring their pets to a veterinary clinic. There are infectious and non-infectious forms of urocystitis as distinguished by the etiology. Urocystitis of non-infectious origin appears due to irritation of the mucous membrane of the bladder with chemical substances from the urine, in particular by drugs if used for prolonged periods at high doses, due to burns of the mucous membrane, for example, in the case of introduction into the bladder of concentrated solution of a chemical substance, as a result of washing the urinary bladder with a solution, the temperature of which exceeds $45^{\circ} \mathrm{C}$ (burning urocystitis), in the case of damage to the mucous membrane by a foreign body, urinary stone, and also during endoscopic study (Dorsch et al., 2016).

There is evidence of predisposition of certain cat breeds to certain diseases of the urinary tract. In particular, Persian, Himalayan and Russian blue cats have a greater risk of developing urocystolithiasis, which is a complication of urocystitis. The stones irritate the surface of the mucous membrane of the bladder and create a supportive environment for the reproduction of bacteria (Ergin et al., 2018).

In most cases, an infection begins soon after the onset of aseptic inflammatory process. For urocystitis of infectious nature, which occurs much more often than the same of non-infectious genesis, the pathogens often are E. coli, staphylococci, streptococci, enterococci and vulgar protium, sometimes gas-producing microorganisms. In the case of urinary tract infection, antimicrobial agents are used to treat urocystitis. For initial therapy, amoxicillin (11-15 mg/kg PO q8h) or trimethoprim sulfonamide (15 mg/kg PO q12h), amoxicillin with clavulanic acid (12.5$25.0 \mathrm{mg} / \mathrm{kg}$ PO q8h) can be used (Weese et al., 2011; Jessen et al., 2015). There are data on the involvement of viruses as pathogens in the etiopa- 
thogenesis of some forms of lower urinary tract disease in cats (Kruger \& Osborne, 1990). One of the causes of diseases of the urinary tract in cats is fungal infection. The most common symptoms are dysuria, hematuria, increased frequency of urination, anorexia, depression and pyrexia. Several species of fungi have been identified in affected animals. Candida albicans is the most common. In most animals with fungal urinary tract infection, there are also other concomitant diseases. In particular, urocystitis, urethritis, diabetes mellitus, neoplasia, renal insufficiency (Adamama-Moraitou et al., 2001; Jin \& Lin, 2005; Bailiff et al., 2006).

One of the main causative factors of a number of diseases of the urinary tract in domestic cats is feed. Such diseases include urolithiasis, in which various types of uroliths (crystals or stones) are formed in the urinary tract. It was determined that the risk of formation of streaky crystals decreases if urine $\mathrm{pH}<6.6$. Whereas the formation of crystals of calcium oxalate occurs at a higher $\mathrm{pH}$ value of urine. Feeding cats with food with the addition of acidifying agents (such as ammonium chloride, calcium chloride, methionine) reduces the urine $\mathrm{pH}$ to prevent the formation of streaks (Finke \& Litzenberger, 1992; Hesse et al., 1998; Markwell et al., 1998; Bailiff et al., 2008).

Thus, an accurate diagnosis is a necessaty for the effective treatment of urocystitis in cats. Early diagnosis, especially differential diagnosis of acute and chronic secondary urocystitis is difficult. Therefore, it is important to combine the methods of visual diagnosis (ultrasound echogramphy), laboratory blood work and urine tests, anamnesis and clinical examination for the diagnosis.

The purpose of this study was to characterize the clinical status of cats with acute urocystitis, and to analyze the informativeness of ultrasonography, blood and urine indexes, and the effectiveness of urocystitis treatment in cats using the medication Cystocure (Candioli Farmaceutici) in combination with antimicrobial and spasmolytic agents. This combination of methods of diagnosis and treatment of urocystitis in cats has not previously been investigated and represents a scientific novelty.

\section{Materials and methods}

During the experimental studies, all manipulations with animals that were involved in the experiment were conducted in accordance with the European Convention on the Protection of Vertebrate Animals used for Experimental and Scientific Purposes (Strasbourg, 1986) and the General Ethical Principles of Animal Experiments, adopted by the First National Congress of Bioethics (Kyiv, 2001) and adhered to the principles of humanity laid down in the directive of the European Community.

The research was conducted during 2016-2018 at the Scientific and Training Clinical and Diagnostic Center of the Faculty of Veterinary Medicine in the Dnipro State Agrarian and Economic University, the Veterinary Clinic "Chotyry lapy", Dnipro, Ukraine. For this study we selected 16 cats from the total number of animals with urocystitis (two groups of 8 animals/group) with an average body weight of $3-5 \mathrm{~kg}$, and age 3-6 years. Blood and urine samples were collected on admission of animals to the clinic, then on the 7th day of treatment. In the blood samples, the number of leukocytes, erythrocytes and thrombocytes, the values of erythrocyte indices and haematocrit, the hemoglobin concentration were measured using the automated haematology analyser PCE 90-Vet (High Technology, USA). The differential leukocyte count was performed in blood smears stained by Wright-Giemsa under a light microscope (Olympus CH 20). Blood tests such as serum contents of total protein, albumin, globulin, glucose, cholesterol, urea, creatinine, bilirubin, and some minerals (calcium, phosphorus) were performed on a semi-automatic biochemical analyzer Rayto 1904Vet using Felicit diagnostic kits Felicit "Phyllis-Diagnosis" (Ukraine).

Samples of urine were analyzed for $\mathrm{pH}$, protein, ketones, urobilinogen, bilirubin, glucose and blood using diagnostic tests Combur10 Test ${ }^{\mathbb{B}} \mathrm{M}$ (Roche Diagnostics). Relative density of urine was determined on a refractometer. Microscopic examination of urine sediment was carried out using a light microscope (Olympus CH 20), first under a low magnifycation $\left({ }^{\times} 10\right)$, then at higher magnification $\left({ }^{\times} 40\right)$ with a lowered condenser. The result was expressed by the number of elements found in the field of view: erythrocytes, leukocytes, epithelial cells, salt crystals (Fig. 1). Sonography was used as the method of visual diagnostics. The in- vestigations were carried out on the Sono Ace 6000 ultrasound machine using a linear sensor of $45 \mathrm{~mm}$ at a frequency of $7.5 \mathrm{MHz}$. Bladder tests were performed along the white line of the cranial pubic jointing. The criterion for differential diagnosis of acute and chronic urocystitis was the thickness of the wall of the bladder, which in healthy cats is $2 \mathrm{~mm}$. In cats with acute urocystitis, the thickness of the wall of the bladder increases by 1.5 times, with chronic - by 2 times or more (Kealy et al., 2011).

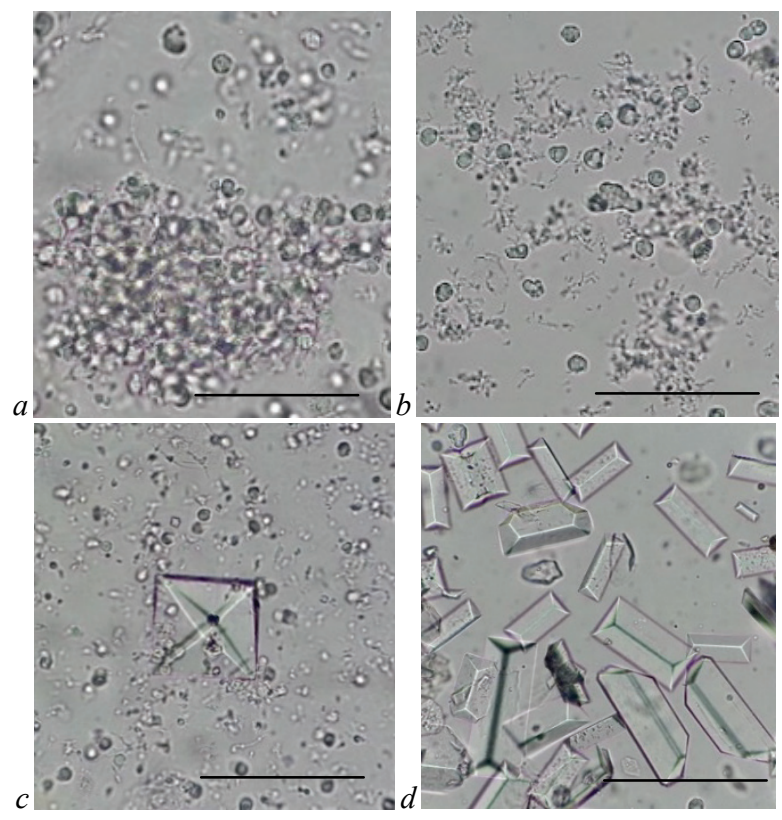

Fig. 1. Residue in the urine in cats with urocystitis:

$a$ - congestion of leukocytes; $b$ - red blood cells and bacteria; $c$-crystals of struvites; $d$-crystals of calcium oxalate; bar $-50 \mu \mathrm{m}$

With therapeutic purpose, sick cats of both groups were administered: anti-microbial agent $-5 \%$ solution of Enrofloxacin, intramuscularly in a dose of $5 \mathrm{mg} / \mathrm{kg}$ once a day for 5 days; spasmolytic medicinal agent Riabal $^{\circledR}$ in a dose of $1 \mathrm{mg} / \mathrm{kg}$ once a day for 5 days. Animals of the second group additionally were administered the drug Cystocure (Candioli Farmaceutici) internally in a dose of $1 \mathrm{~g} / 10 \mathrm{~kg}$ twice a day for 15 30 days. According to the instructions, the plant basis of the powder Cystocure is presented by extracts of cranberries $(60.000 \mathrm{mg} / \mathrm{kg})$ and orange peel $(200.000 \mathrm{mg} / \mathrm{kg})$. These substances provide the main properties of the drug - help to resist the bacterial colonization of the lower urinary tract and change urine $\mathrm{pH}$ to the acid side. Extract of cranberries included in the composition contains benzoic acid, which increases the effect of antibiotics and sulfanilamides. Cranberries contain citric, chinic, benzoic and oleic acids, vitamins $\mathrm{C}$ and $\mathrm{P}$, carotene, saponins, amino acids, routine, quercetin, glycoside, microelements (iodine, iron, copper, manganese) (Liu et al., 2006; Gupta et al., 2007).

The experimental data analysis was performed using the ANOVA method. The numerical data in the tables are presented as $\mathrm{x} \pm \mathrm{SD}$. According to the results of the ANOVA method, reliably different samples were marked by ${ }^{*}-\mathrm{P}<0.05 ;{ }^{* *}-\mathrm{P}<0.01$; *** $-\mathrm{P}<0.001$.

\section{Results}

Analyzing the reports for the last three years, it was found that among all diseases of cats with which the owners turn to the clinic, diseases of non-contagious etiology account for $71-74 \%$, and diseases of contagious etiology - respectively 29-26\% (Table 1).

\section{Table 1}

The proportion of diseases of contagious and non-contagious etiology among all cats' diseases in 2016-2018

\begin{tabular}{cccccc}
\hline \multirow{2}{*}{$\begin{array}{c}\text { Years of } \\
\text { study }\end{array}$} & \multirow{2}{*}{$\begin{array}{c}\text { Total amount } \\
\text { of sick cats }\end{array}$} & \multicolumn{2}{c}{$\begin{array}{c}\text { Cats with diseases } \\
\text { of non-contagious etiology }\end{array}$} & \multicolumn{2}{c}{$\begin{array}{c}\text { Cats with diseases } \\
\text { of contagious etiology }\end{array}$} \\
\cline { 3 - 6 } & & amount & $\%$ & amount & $\%$ \\
\hline 2016 & 4000 & 2980 & 74.5 & 1020 & 25.5 \\
2017 & 4323 & 3071 & 71.0 & 1252 & 29.0 \\
2018 & 4108 & 2951 & 71.8 & 1157 & 28.2 \\
\hline
\end{tabular}


Among the diseases of non-pathogenic etiology, pathologies of the gastrointestinal tract were registered more often than cardiovascular diseases, respiratory diseases and diseases of the urinary system $-18.7 \%$ (Fig. 2). Among diseases of non-contagious etiology of cats for the last three years, urocystitis is registered in $10-11 \%$ of cases. This indicates a significant prevalence of this disease among cats. In particular, in 2016 there were 329 cases of cats with urocystitis, in 2017 - 340, in 2018 346 cases.

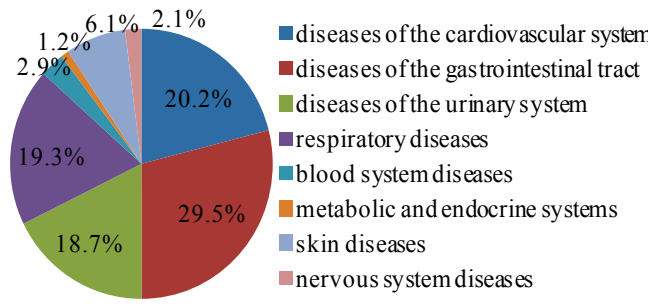

Fig. 2. Diseases of urinary system among internal pathologies in the percentage ratio in cats: $n=2951$

Studying the question of the presence of urocystitis in relation to the age of cats, we found that most often the pathology is observed in older animals. Probably this is due to the lifestyle of cats of these age categories, their ration, and the decrease in natural resistance (Fig. 3).

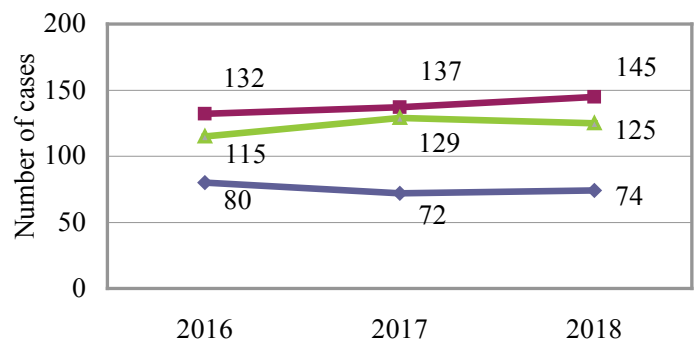

Fig. 3. Age dynamics of urocystitis in cats: - cats aged under 3, - cats aged 3-7, $=-$ cats over 7 years of age

The sex did not affect the occurrence of this pathology, urocystitis was observed with the same frequency in females and males. In particular, in 2016, 169 and 160 cases were registered in females and males respectively, in 2017 - 163 and 177, in 2018 - 160 and 186. The incidence of urocystitis in cats depended on the season of the year (Fig. 4). Epidemic outbreaks in cats were observed in the spring and fall periods. The epidemic duration in the spring is 4 months (February, March, April, May), in the fall -3 months (September, October, November).

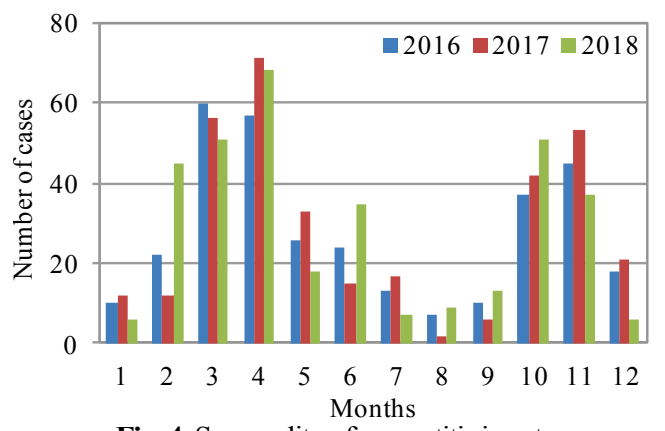

Fig. 4. Seasonality of urocystitis in cats

Urocystitis in cats most often occurs in the following forms: primary acute, acute purulent, secondary urocystitis as a complication of urolithiasis and pyelonephritis (Fig. 5). From the anamnesis data, it was found that in the course of several days the animals experienced appetite loss, apathy, and urinary tract disorder before they were brought to the veterinary clinic. Clinically acute urocystitis has always been manifestted by disorders of urination. Cats often assumed the posture for urination, but the urine flowed in small portions, which was accompanied by severe tension of the abdominal muscles (pollakiuria, dysuria). During the act of urination, the animals showed anxiety and painful sensations (stranguria). Some of the animals showed an increase in body temperature, pain in the bladder and tightness of the walls of the abdominal space.

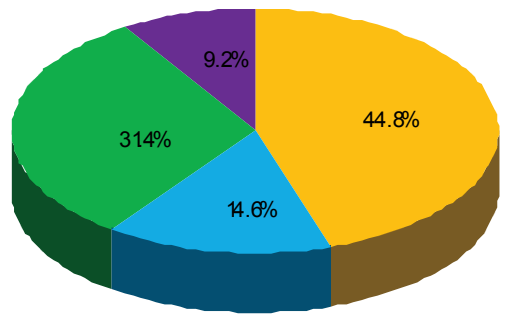

Fig. 5. Forms of urocystitis in cats: $n=346 ;-$ - primary acute urocystitis, - acute purulent urocystitis, - - secondary urocystitis as a complication of urolithiasis, - urocystitis as a complication of pyelonephritis

According to the results of Ultra Sonic Testing, changes in the bladder were observed depending on the form of the disease, which was typical for most sick animals. Figure $6 a$ shows the results of Ultra Sonic Testing of the bladder of the cat Chief with acute urocystitis, which arose as a complication of urolithiasis. It was found that the bladder had the correct form, the contour was even, clear. In the cavity of the bladder a concrement of irregular shape with a width of $11.8 \mathrm{~mm}$ in the widest region was determined. The thickness of the wall of the bladder was $3.5 \mathrm{~mm}$, which corresponds to the acute course of urocystitis.

Figure $6 b$ shows the results of ultrasound investigation of the bladder of the cat Lot with acute urocystitis. The thickening of the mucous membrane of the bladder wall was detected. In the cavity of the bladder, a conglomerate of hyperherogenic concrements was determined, creating a dense ultrasound shadow. Figure $6 c$ shows the results of ultrasound investigation of the bladder of the cat Miki with chronic urocystitis. It was found that the bladder had the correct form, the contour was even, clear. Significant hyperplasia was observed, thickening of the wall $5.1 \mathrm{~mm}$. Epithelium was hyperherogenic. In the cavity of the bladder there was a large amount of crystalline suspension.

According to the results of urine study, it was found that its colour was different - from light pale to dark red or even muddy green in the case of purulent processes in the bladder (Table 2).

Table 2

Indicators of urine of cats of the I group with acute urocystitis $(x \pm S D)$

\begin{tabular}{lccc}
\hline \multicolumn{1}{c}{ Indications } & Norm & $\begin{array}{c}\text { Before the } \\
\text { treatment }\end{array}$ & $\begin{array}{c}\text { After the } \\
\text { treatment }\end{array}$ \\
\hline Specific gravity, g/L & $1015-1045$ & $1046 \pm 6$ & $1030 \pm 4^{* * *}$ \\
$\mathrm{pH}$ & $5.0-6.5$ & $7.06 \pm 0.82$ & $6.81 \pm 0.53$ \\
Protein, g/L & $0-0.1$ & $0.74 \pm 0.36$ & $0.13 \pm 0.07^{* * *}$ \\
Red blood cells, cells in sight & $0-2$ & $15.25 \pm 6.76$ & $1.75 \pm 0.89^{* * *}$ \\
White blood cells, cells in sight & $0-2$ & $36.38 \pm 14.33$ & $2.13 \pm 0.83^{* * *}$ \\
Pavement epithelium, cells in sight & $0-5$ & $3.28 \pm 1.30$ & $1.98 \pm 1.07^{*}$ \\
Epithelium transient, cells in sight & $0-2$ & $3.25 \pm 1.04$ & $1.63 \pm 0.74^{* *}$ \\
\hline
\end{tabular}

Note: ${ }_{-} \mathrm{P}<0.05$; ** $-\mathrm{P}<0.01 ; * * *-\mathrm{P}<0.001$; ANOVA method.

In 7 of $16(43.7 \%)$ cats, an increase in the relative density of urine was noted. In $56.2 \%$ of cats, urine $\mathrm{pH}$ exceeded 7.0. All animals had cloudy urine, proteinuria. In the urine sediment of the sick cats we detected red blood cells, leukocytes and microorganisms, and $58.4 \%$ of the cats were contaminated with salt and sand (Table 3). Using laboratory blood tests in cats of both groups, an increase in the rate of neutrophil leukocytosis was determined. The functional state of the kidneys was evaluated by the content of urea and creatinine in the blood serum (Table 4). The content of urea in the blood of cats with acute urocystitis was in the range from 5.2 to $16.7 \mathrm{mmol} / \mathrm{L}$. An increase in blood serum of urea content was found in seven of the total number of cats $(43.7 \%)$ (Table 5). In these animals, the indicator ranged from 10.2 to $16.7 \mathrm{mmol} / \mathrm{L}$. An increase in the blood serum creatinine content was observed in 8 of $16(50.0 \%)$ cats. In these animals, creatinine levels ranged from 145 to $178 \mu \mathrm{mol} / \mathrm{L}$. The increase of urea and creatinine was due to edema and ureter enlargement, which had led to pyelectasis and the development of postrenal renal failure in these animals. 

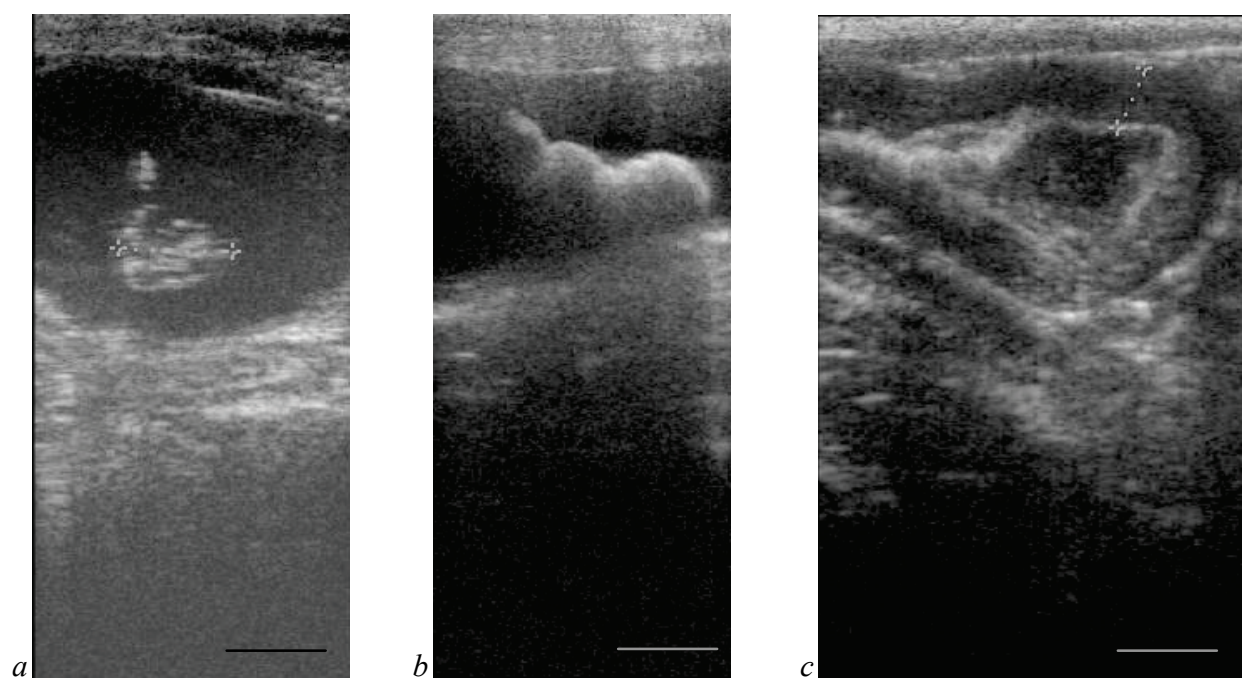

Fig. 6. Results of Ultra Sonic Testing of the bladder of cats:

Chief with acute urocystitis as a complication of urolithiasis $(a)$, Lot with acute urocystitis $(b)$, Miki with chronic urocystitis $(c)$; bar - $10 \mathrm{~mm}$

Table 3

Indicators of urine of cats of the II group with acute urocystitis $(\mathrm{x} \pm \mathrm{SD})$

\begin{tabular}{lccc}
\hline \multicolumn{1}{c}{ Indications } & Norm & $\begin{array}{c}\text { Before the } \\
\text { treatment }\end{array}$ & $\begin{array}{c}\text { After the } \\
\text { treatment }\end{array}$ \\
\hline Specific gravity, g/L & $1015-1045$ & $1047 \pm 7$ & $1029 \pm 4^{* * *}$ \\
$\mathrm{pH}$ & $5.0-6.5$ & $7.06 \pm 0.78$ & $6.25 \pm 0.38^{*}$ \\
Protein, g/L & $0-0.1$ & $0.74 \pm 0.36$ & $0.13 \pm 0.07^{* * *}$ \\
Red blood cells, cells in sight & $0-2$ & $16.63 \pm 4.17$ & $1.13 \pm 0.35^{* * *}$ \\
White blood cells, cells in sight & $0-2$ & $35.38 \pm 13.41$ & $1.25 \pm 0.71^{* * *}$ \\
Pavement epithelium, cells in sight & $0-5$ & $3.15 \pm 1.13$ & $1.25 \pm 0.46^{* * *}$ \\
Epithelium transient, cells in sight & $0-2$ & $3.15 \pm 1.12$ & $1.13 \pm 0.35^{* * *}$ \\
\hline
\end{tabular}

Note: see Table 2.

Table 4

Biochemical parameters of blood of cats of the I group with acute urocystitis $(x \pm \mathrm{SD})$

\begin{tabular}{lccc}
\hline \multicolumn{1}{c}{ Indications } & Norm & $\begin{array}{c}\text { Before the } \\
\text { treatment }\end{array}$ & $\begin{array}{c}\text { After the } \\
\text { treatment }\end{array}$ \\
\hline Total protein, $\mathrm{g} / \mathrm{L}$ & $55-75$ & $63.3 \pm 4.1$ & $64.3 \pm 4.9$ \\
Albumin, $\mathrm{g} / \mathrm{L}$ & $25-38$ & $29.8 \pm 3.5$ & $30.6 \pm 3.5$ \\
Globulins, $\mathrm{g} / \mathrm{L}$ & $30-37$ & $33.7 \pm 1.8$ & $33.7 \pm 2.3$ \\
Urea, $\mathrm{mmol} / \mathrm{L}$ & $3.3-9.0$ & $10.2 \pm 3.9$ & $7.6 \pm 2.1$ \\
Creatinine, $\mu \mathrm{mol} / \mathrm{L}$ & $45-135$ & $131 \pm 38$ & $113 \pm 32$ \\
Total bilirubin, $\mu \mathrm{mol} / \mathrm{L}$ & $0.4-7.0$ & $1.62 \pm 0.84$ & $1.25 \pm 0.95$ \\
Glucose, $\mathrm{mmol} / \mathrm{L}$ & $3.6-7.2$ & $4.93 \pm 0.76$ & $5.01 \pm 0.81$ \\
Total calcium, $\mathrm{mmol} / \mathrm{L}$ & $2.2-3.0$ & $2.51 \pm 0.23$ & $2.49 \pm 0.19$ \\
Inorganic phosphorus, $\mathrm{mmol} / \mathrm{L}$ & $0.9-2.0$ & $1.48 \pm 0.19$ & $1.42 \pm 0.17$ \\
Cholesterol, $\mathrm{mmol} / \mathrm{L}$ & $3.6-6.6$ & $4.31 \pm 0.78$ & $4.31 \pm 0.50$ \\
\hline
\end{tabular}

Note: see Table 2.

\section{Table 5}

Biochemical parameters of blood of cats of the II group with acute urocystitis $(\mathrm{x} \pm \mathrm{SD})$

\begin{tabular}{lccc}
\hline \multicolumn{1}{c}{ Indications } & Norm & $\begin{array}{c}\text { Before the } \\
\text { treatment }\end{array}$ & $\begin{array}{c}\text { After the } \\
\text { treatment }\end{array}$ \\
\hline Total protein, g/L & $55-75$ & $63.1 \pm 5.7$ & $63.4 \pm 3.6$ \\
Albumin, $\mathrm{g} / \mathrm{L}$ & $25-38$ & $29.7 \pm 4.3$ & $31.2 \pm 2.5$ \\
Globulins, $\mathrm{g} / \mathrm{L}$ & $30-37$ & $23.5 \pm 2.4$ & $32.2 \pm 2.2$ \\
Urea, $\mathrm{mmol} / \mathrm{L}$ & $3.3-9.0$ & $9.8 \pm 4.2$ & $6.5 \pm 1.6^{*}$ \\
Creatinine, $\mu \mathrm{mol} / \mathrm{L}$ & $45-135$ & $129 \pm 39$ & $79 \pm 15^{* *}$ \\
Total bilirubin, $\mu \mathrm{mol} / \mathrm{L}$ & $0.4-7.0$ & $1.69 \pm 1.21$ & $1.61 \pm 0.83$ \\
Glucose, $\mathrm{mmol} / \mathrm{L}$ & $3.6-7.2$ & $4.87 \pm 1.03$ & $5.13 \pm 0.72$ \\
Total calcium, $\mathrm{mmol} / \mathrm{L}$ & $2.2-3.0$ & $2.61 \pm 0.28$ & $2.58 \pm 0.26$ \\
Inorganic phosphorus, $\mathrm{mmol} / \mathrm{L}$ & $0.9-2.0$ & $1.51 \pm 0.23$ & $1.39 \pm 0.17$ \\
Cholesterol, $\mathrm{mmol} / \mathrm{L}$ & $3.6-6.6$ & $4.52 \pm 0.75$ & $4.63 \pm 0.71$ \\
\hline
\end{tabular}

\section{Note: see Table 2.}

The applied therapy positively influenced the clinical condition of the cats of both groups. Their general condition improved, body temperature was within normal limits, appetite returned, painful sensations during the act of urination disappeared, the number and frequency of diuresis normalized. In the process of treatment, there was a decrease in the rate of the number of white blood cells in the cats of both groups (Table 6). The number of leukocytes in cats of the first group decreased by $41.5 \%$, in cats of the second group - by $47.7 \%$. The ratio of leukocytes was in the normal range (Table 7).

Table 6

Hematological indices of cats of the I group with acute urocystitis $(x \pm S D)$

\begin{tabular}{lccc}
\hline \multicolumn{1}{c}{ Indications } & Norm & $\begin{array}{c}\text { Before the } \\
\text { treatment }\end{array}$ & $\begin{array}{c}\text { After the } \\
\text { treatment }\end{array}$ \\
\hline Hemoglobin, g/L & $93-153$ & $126 \pm 12$ & $138 \pm 66^{*}$ \\
Packed cell volume, \% & $28-49$ & $37.6 \pm 3.9$ & $41.5 \pm 4.4$ \\
Red blood cells, $10^{12} / \mathrm{L}$ & $4-7$ & $4.75 \pm 0.71$ & $4.89 \pm 0.58$ \\
Mean cell volume, $10^{-15} \mathrm{~L}$ & $80-100$ & $79.9 \pm 7.1$ & $85.5 \pm 7.4$ \\
Mean cell hemoglobin, $10^{-12} \mathrm{~g}$ & $27-31$ & $27.1 \pm 3.4$ & $28.6 \pm 2.6$ \\
Mean cell hemoglobin & $33-73$ & $34.8 \pm 3.9$ & $34.6 \pm 2.3$ \\
concentration, \% & $160-500$ & $236 \pm 67$ & $284 \pm 88$ \\
Platelets, $10^{9} / \mathrm{L}$ & $8.5-16.0$ & $17.1 \pm 5.4$ & $9.8 \pm 0.9^{* *}$ \\
White blood cells, $10^{9} / \mathrm{L}$ & $0-6$ & $2.13 \pm 1.73$ & $2.45 \pm 1.04$ \\
Eosinophils, $\%$ & $2-6$ & $7.13 \pm 1.46$ & $3.98 \pm 1.31^{* * *}$ \\
Neutrophils banded, \% & $45-70$ & $59.5 \pm 8.7$ & $61.5 \pm 5.8$ \\
Neutrophils segmented, \% & $20-40$ & $26.1 \pm 6.2$ & $31.2 \pm 5.9$ \\
Lymphocytes, \% & $2-6$ & $4.25 \pm 1.28$ & $4.51 \pm 0.93$ \\
Monocytes, \% & & &
\end{tabular}

Note: see Table 2.

Table 7

Hematological indices of cats of the II group with acute urocystitis $(x \pm S D)$

\begin{tabular}{lccc}
\hline \multicolumn{1}{c}{ Indications } & Norm & $\begin{array}{c}\text { Before the } \\
\text { treatment }\end{array}$ & $\begin{array}{c}\text { After the } \\
\text { treatment }\end{array}$ \\
\hline Hemoglobin, g/L & $93-153$ & $128 \pm 14$ & $140 \pm 6^{*}$ \\
Packed cell volume, \% & $28-49$ & $38.6 \pm 5.4$ & $41.8 \pm 2.1$ \\
Red blood cells, $10^{12} / \mathrm{L}$ & $4-7$ & $5.12 \pm 0.70$ & $5.24 \pm 0.45$ \\
Mean cell volume, $10^{-15} \mathrm{~L}$ & $80-100$ & $76.1 \pm 6.1$ & $80.1 \pm 9.5$ \\
Mean cell hemoglobin, $10^{-12} \mathrm{~g}$ & $27-31$ & $25.3 \pm 2.7$ & $28.1 \pm 1.3$ \\
Mean cell hemoglobin & $33-73$ & $34.5 \pm 3.7$ & $34.6 \pm 1.3$ \\
concentration, \% & $160-500$ & $238 \pm 68$ & $295 \pm 77$ \\
Platelets, $10^{9} / \mathrm{L}$ & $8.5-16$ & $17.4 \pm 4.8$ & $9.1 \pm 0.7^{* * *}$ \\
White blood cells, $10^{9} / \mathrm{L}$ & $0-6$ & $2.01 \pm 1.07$ & $2.38 \pm 0.92$ \\
Eosinophils, \% & $2-6$ & $7.02 \pm 1.51$ & $4.25 \pm 1.04^{* * *}$ \\
Neutrophils banded, \% & $45-70$ & $59.2 \pm 7.3$ & $62.9 \pm 5.9$ \\
Neutrophils segmented, \% & $20-40$ & $27.2 \pm 7.5$ & $29.1 \pm 4.8$ \\
Lymphocytes, \% & $2-6$ & $3.48 \pm 0.92$ & $3.65 \pm 1.19$ \\
Monocytes, \% & & &
\end{tabular}

Note: see Table 2.

The functional status of the kidneys of the sick animals also improved: urea content in the blood serum of cats of the first group decreased to $2.5 \mathrm{mmol} / \mathrm{L}(25.0 \%)$ by the 7 th day of treatment, and in 2 out of 8 $(25.0 \%)$ animals its content exceeded the norm. Significant difference in 
blood biochemical parameters in cats of the first group after treatment was not established (Table 4).

In cats of the second group (which additionally received the drug Cystocure) the urea content in the blood serum decreased by $3.4 \mathrm{mmol} / \mathrm{L}$ (34.6\%), and its content was within the normal range in all animals. The creatinine content in the blood serum of cats of the first group on the 7 th day of treatment decreased to $17.6 \mu \mathrm{mol} / \mathrm{L}(13.5 \%)$, in three out of eight (37.5\%) animals its content exceeded the norm. In cats of the second group, creatinine content in the blood serum decreased to $50.1 \mu \mathrm{mol} / \mathrm{L}(38.9 \%)$, and its content was within the normal range in all animals (Table 5). By the seventh day of treatment in cats of both groups, the urine became transparent, the presence of microorganisms was not detected, the amount of salts and sand decreased significantly by the seventh day of treatment in cats of both groups. In animals of both groups, the content of proteins, red blood cells, white blood cells and epithelial cells (Table 2 and 3 ) in the urine decreased after treatment. Thus, the use of Enrofloxacin for cats of both groups provides a broad spectrum of antimicrobial action during periods of urocystitis and does not exhibit nephrotoxicity. This is evidenced by the normal level of urea and creatinine in the blood serum.

An important criterion is the normal $\mathrm{pH}$ of the urine. In cats of the second group, the $\mathrm{pH}$ of the urine was lower after treatment, compared to the animals of the first group. In $87.5 \%$ of cats of the second group, which additionally used the drug Cystocure, urine $\mathrm{pH}$ was within 6.0 6.5 , only in one animal -7.0 . In $50.0 \%$ of cats of the first group - the $\mathrm{pH}$ of the urine was within the range of 7.0-7.5, thus the displacement of urine $\mathrm{pH}$ to the alkaline side continued. Consequently, the use of the drug Cystocure is recommended in addition to antimicrobial and antispasmodic drugs, as this maintains $\mathrm{pH}$ of urine within the recommended limits and prevents the development of complications, and in the case of secondary urocystitis - prevents the progression of urolithiasis.

\section{Discussion}

Different methods of visual diagnosis (for example, roentgenography, cystography, ultrasonography and ureteroscopy) are used for the diagnosis of diseases of the urinary tract. Using the method of roentgenography we can determine the anatomical location and shape of the bladder, the presence of radio-opaque uroliths with a diameter of over $3 \mathrm{~mm}$, bladder anomalies, calcification of the bladder wall and accumulation of gases. Positive/negative or double contrast roentgenograpy and ultrasonography of the abdominal organs allow a detailed study of the bladder to diagnose urocystitis by measuring the thickness of the bladder wall, detecting stones, blood clots, bladder rupture, neoplasia, dislocation and diverticulum (Farrow, 2003; Hostutler et al., 2005; Kealy et al., 2011). The use of cytokines as potentially non-invasive biomarkers for the diagnosis and determination of the effectiveness of treatment of idiopathic urocystitis in cats is suggested (Parys et al., 2018). There is an announcement that the use of immunostimulants of bacterial origin are best suited for treatment of this pathology, in particular UroVaxom $^{\circledR}$, as one of its mechanisms of action is the formation of specific immunoglobulins and activation of cellular immunity (Semyonov et al., 2015).

Clearly, comprehensive studies of this pathology are the most effective. Thereby, we proposed an effective combination of methods for diagnosis of urocystitis and its cure. The use of Enrofloxacin produced an antimicrobial effect and led to the normalization of urea and creatinine levels in blood serum. The use of Riabal ${ }^{\mathbb{B}}$ reduced or completely eliminated spasms, pain and relieved urination. The active ingredient of the drug Riabal ${ }^{\circledR}$ is prifinium bromide, $5 \mathrm{ml}$ of syrup containing $7.5 \mathrm{mg}$ of prifinium bromide.Riabal selectively blocks peripheral m-cholinoreceptors of the mucous membrane of the digestive tract, bile passages, urinary tract and uterus. Thus, Riabal ${ }^{\circledR}$ makes them insensitive to acetylcholine formed at the end of the postganglionic parasympathetic nerves. The result is a decrease in the unstriated muscles tone of the esophagus, intestines, gall bladder, bile passages, urinary tract and uterus, as well as a decrease of the secretion of hydrochloric acid, pepsin, and a decrease of the external secretion activity of the pancreas.

And the use of medication Cystocure (Candioli Farmaceutici) for the cats of the second group allowed urine $\mathrm{pH}$ to be maintained within the recommended limits thanks to its diuretic, anti-inflammatory and antiseptic properties. The result was restoration of the bladder function and normalization of the clinical condition, blood and urine values in cats. Extracts of cranberries and orange peels provide the main properties of the drug Cystocure. American cranberries (cranberries extract) contain special natural tannins called proanthocyanidins, which restrain adhesion of E. coli of P-type fimbriae (Liu et al., 2006; Gupta et al., 2007). This delay is provided by the structural change in protein molecules of fimbriae and the consistent reduction of their adhesion influence to the epithelial cell surface (Di Martino et al., 2006; Jepson \& Craig, 2008). A-type proanthocyanidins, which are contained in American cranberries, have 200 times more antiadhesive action than B-type proanthocyanidins, contained in grape or completely inactive proanthocyanidins contained in apples and green tea (Howell, 2007; Lavigne et al., 2007). Another component, fructose, is able to inhibit the E. coli of Itype fimbriae adhesion (Heinonen, 2007; Eydelnant \& Tufenkji, 2008). Thus, cranberries have a therapeutic effect for infections of the urinary tract and urocystitis. Orange peel extract (citrus bioflavonoids) reduce oxidative and inflammatory processes in the urinary tract. In the group of glycoside substances derived from citrus and epicarp of other plants the most typical is hesperidine. It performs a protective function to provide the integrity of the urothelium cells due to its significant antioxidant activity (Dreikorn, 2005; Wynn \& Fougère, 2007). It prevents lipoperoxidation of cell membranes and activates some important antioxidant endogenous systems: catalase, GSH (glutathione), SOD (superoxide dismutase). It neutralizes the activity of free radicals and reduces the activity of some inflammatory mediators (chemokines, xanthine oxidase) (Park et al., 2008)

Regardless of etiology, the clinical features of urocystitis are similar and include dysuria, stranguria, hematuria, pollakiuria. Urine reaction during urocystitis caused by $E$. coli is usually acid, that caused by other microorganisms is alkaline. The urease active bacteria join the primary infection, which decays urea with the formation of ammonia, causing the urine reaction to change to the alkaline side with a characteristic smell of ammonia and carry-down of amorphous-crystalline phosphates and struvites. The composition of urine and $\mathrm{pH}$ is directly and closely related to the mineral composition (Kienzle et al., 1991). The presence of protein in the urine is due to the presence of an inflammatory exudate. Its amount is higher in purulent cystitis than in catarrhal cystitis, but does not exceed $1.0 \mathrm{~g} / \mathrm{L}$ (Hostutler et al., 2005). Currently, it is recommended to maintain urine $\mathrm{pH}$ in adult cats in the range 6.0-6.4. This will minimize the risk of struvite formation and the development of urolithiasis, one of the common complications of which is urocystitis (Cottam et al., 2002).

Our studies showed similar changes in urine in protein content, $\mathrm{pH}$, the presence of red blood cells and leukocytes under the influence of urocystitis. In general, treatment of animals of both groups led to positive changes in the urine composite. The protein content, the number of red blood cells, leukocytes and epithelial cells stabilized within the norm. There was a visible decrease in blood levels of erythrocyte sedimentation, the total number of leukocytes, the percentage of band forms and creatinine content in the experimental cats as a result of our treatment. Biochemical parameters of the blood were within the norm.

\section{Conclusions}

Urocystitis in cats is most often manifested in the following forms, taken as percentages of 346 animals with the disease: primary acute $44.8 \%$, acute purulent $-14.6 \%$, secondary urocystitis, as a complication of urolithiasis $-31.4 \%$ and urocystitis, as the complication of pyelonephritis $-9.2 \%$. The disease is most common in older animals. The influence of sex of cats on occurrence of this pathology is not established. Urocystitis was found with similar frequency both in males and females. The season of the year influenced the occurrence of urocystitis. Most often this was observed in spring (February, March, April, May), and autumn (September, October, November).

Early diagnosis, including differential diagnosis of acute and chronic secondary urocystitis is difficult. An ultrasonographic study revealed thickening of the bladder wall. The criterion for differential diagnosis of 
acute and chronic urocystitis was the thickness of the bladder wall, which in healthy cats is $2 \mathrm{~mm}$. For acute urocystitis, the thickness of the wall of the bladder increases by 1.5 times, with chronic urocystitis it does so by 2 or more times.

This study confirms that ultrasonography is an effective method for visual diagnosis of diseases of the urinary tract. Ultrasound echography, laboratory blood and urine tests, anamnesis and clinical studies should be combined in the process of diagnosis.

The applied complex treatment of urocystitis in cats positively influenced the functional recovery of the bladder, manifested by the normalization of the clinical, blood and urine indexes. In cats of the second group, which additionally used the drug Cystocure, the $\mathrm{pH}$ of urine was within the range of $6.3 \pm 0.14(\mathrm{P}<0.05)$, and in animals of the first group is was $6.8 \pm 0.20$. The use of Enrofloxacin provided a broad spectrum of antimicrobial activity for both groups of cats and did not show nephrotoxic effect. This is evidenced by the normal level of urea and creatinine in the blood serum. Riabal ${ }^{\mathbb{B}}$ eliminates cramps and pain, facilitates the act of urination. The additional use by animals of the second group of the drug Cystocure (Candioli Farmaceutici) promotes maintaining urine $\mathrm{pH}$ within the recommended range (6.0-6.4), removing the crystals from the urinary tract. Thus, the use of the drug Cystocure maintains the $\mathrm{pH}$ of urine within the recommended limits, which prevents the development of complications, and in the case of seconddary urocystitis it prevents the progression of urolithiasis.

\section{References}

Adamama-Moraitou, K. K., Paitaki, C. G., Rallis, T. S., \& Tontis, D. (2001) Aspergillus species cystitis in a cat. Journal of Feline Medicine and Surgery, 3(1), 31-34.

Bailiff, N. L., Nelson, R. W., Feldman, E. C., Westropp, J. L., Ling, G. V., Jang, S. S., \& Kass, P. H. (2006). Frequency and risk factors for urinary tract infection in cats with diabetes mellitus. Journal of Veterinary Internal Medicine, 20, 850-855.

Bailiff, N. L., Westropp, J. L., Nelson, R. W., Sykes, J. E., Owens, S. D., \& Kass, P. H. (2008). Evaluation of urine specific gravity and urine sediment as risk factors for urinary tract infections in cats. Veterinary Clinical Pathology, 37(3), 317-322.

Bartges, J. W. (2012). Chronic kidney disease in dogs and cats. Veterinary Clinics: Small Animal Practice, 42(4), 669-692.

Brown, C. A., Jeong, K-S., Poppenga, R. H., Puschner, B., Miller, D. M., Ellis, A. E., Kang, K., Sum, S., Cistola, A. M., \& Brown, S. A. (2007). Outbreaks of renal failure associated with melamine and cyanuric acid in dogs and cats in 2004 and 2007. Journal of Veterinary Diagnostic Investigation, 19, 525-531.

Cottam, Y. H., Caley, P., Wamberg, S., \& Hendriks, W. H. (2002). Feline reference values for urine composition. The Journal of Nutrition, 132(6), 1754-1756.

Di Martino, P., Agniel, R., David, K., Templer, C., Gaillard, J. L., Denys, P., \& Botto, H. (2006). Reduction of Escherichia coli adherence to uroepithelial bladder cells after consumption of cranberry juice: A double-blind randomized placebo-controlled cross-over trial. World Journal of Urology, 24(1), 21-27.

Dorsch, R., Vopelius-Feldt, C., Wolf, G., Mueller, R. S., Straubinger, R. K., \& Hartmann, K. (2016). Tierärztliche praxis kleintiere, 44, 227-236.

Dreikorn, K. (2005). Complementary and alternative medicine in urology. British Journal of Urology, 96(8), 1177-1184.

Ergin, İ., Şen, Y., Şenel, O. O., Özgermen, D. B., \& Bumin, A. (2018). Radiological and ultrasonographical evaluation of lower urinary tract diseases in cats. Veterinary Journal of Ankara University, 65, 73-78.

Eydelnant, I. A., \& Tufenkji, N. (2008). Cranberry derived proanthocyanidins reduce bacterial adhesion to selected biomaterials. Langmuir, 24(18), 10273-10281.

Farrow, C. S. (2003). Kidney, ureteral bladder, prostatic and urethral disease. In: Farrow, C. S. (Ed.). Veterinary diagnostic imaging: The dog and cat. Mosby Inc., Philadelphia.

Finke, M. D., \& Litzenberger, B. A. (1992). Effect of intake on urine pH in cats Journal of Small Animal Practice, 33(6), 261-265.

Grauer, G. F. (2005). Early detection of renal damage and disease in dogs and cats Veterinary Clinics: Small Animal Practice, 35(3), 581-596.

Gupta, K., Chou, M. Y., Howell, A., Wobbe, C., Grady, R., \& Stapleton, A. E. (2007). Cranberry products inhibit adherence of p-fimbriated Escherichia coli to primary cultured bladder and vaginal epithelial cells. The Journal of Urology, 177(6), 2357-2360.

Heinonen, M. (2007). Antioxidant activity and antimicrobial effect of berry phenolics a Finnish perspective. Molecular Nutrition Food Research, 51(6), 684-691.
Hesse, A., Steffes, H.-J., \& Graf, C. (1998). Pathogenic factors of urinary stone formation in animals. Journal of Animal Physiology and Animal Nutrition, 80, 108-119.

Hostutler, R. A., Chew, D. J., \& DiBartola, S. P. (2005). Recent concepts in feline lower urinary tract disease. Veterinary Clinics: Small Animal Practice, 35(1), 147-170.

Howell, A. B. (2007). Bioactive compounds in cranberries and their role in prevention of urinary tract infections. Molecular Nutrition Food Research, 51(6), 732-737.

Jepson, R. E., Elliott, J., Brodbelt, D., \& Syme, H. M. (2007). Effect of control of systolic blood pressure on survival in cats with systemic hypertension. Journal of Veterinary Internal Medicine, 21(3), 402-409.

Jepson, R., \& Craig, J. (2008). Cranberry for preventing urinary tract infections. Cochrane Database of Systematic Reviews, 23(1), CD001321.

Jessen, L. R., Sorensen, T. M., Bjomvad, C. R., Saxmose Nielsen, S., \& Guardabassi, L. (2015). Effect of antibiotic treatment in canine and feline urinary tract infections: A systematic review. The Veterinary Journal, 203(3), 270-277.

Jin, Y., \& Lin, D. (2005). Fungal urinary tract infections in the dog and cat: A retrospective study (2001-2004). Journal of the American Animal Hospital Association, 41(6), 373-381.

Kealy, J. K., Mcallister, H., \& Graham, J. P. (2011). The abdomen. Diagnostic radiology and ultrasonography of the dog and cat. Saunders Elsevier, USA. Pp. 23-198.

Kienzle, E., Schuknecht, A., \& Meyer, H. (1991). Influence of food consumption on the urine $\mathrm{pH}$ in cats. The Journal of Nutrition, 121, 87-88.

Kruger, J. M., \& Osborne, C. A. (1990). The role of viruses in feline lower urinary tract disease. Journal of Veterinary Internal Medicine, 4(2), 71-78.

Kumar, V., Kumar, A., \& Varshney, A. C. (2011). Ultrasonographic imaging for structural characterization of renal affections and diagnosis of associated chronic renal failure in 10 dogs. ISRN Veterinary Science, 2011, ID 901713.

Lavigne, J.-P., Bourg, G., Botto, H., \& Sotto, A. (2007). Cranberry (Vaccinium macrocarpon) and urinary tract infections: study model and review of literature. Pathologie Biologie (Paris), 55(8-9), 460-464.

Liu, Y., Black, M. A., Caron, L., \& Camesano, T. A. (2006). Role of cranberry juice on molecular-scale surface characteristics and adhesion behavior of E. coli. Biotechnology and Bioengineering, 93(2), 297-305.

Markwell, P. J., Buffington, C. T., \& Smith, B. H. E. (1998). The effect of diet on lower urinary tract diseases in cats. The Journal of Nutrition, 128(12), 2753-2757.

O'Neill, D. G., Elliott, J., Church, D. B., McGreevy, P. D., Thomson, P. C., \& Brodbelt, D. C. (2013). Chronic kidney disease in dogs in UK veterinary practices: Prevalence, risk factors, and survival. Journal of Veterinary Internal Medicine, 27, 814-821.

Park, H.-H., Lee, S., Son, H.-Y., Park, S.-B., Kim, M.-S., Choi, E.-J., Singh, T. S. K., Ha, J.-H., Lee, M.-G., Kim, J.-E., Hyun, M. C., Kwon, T. K., Kim, Y.H., \& Kim, S.-H. (2008). Flavonoids inhibit histamine release and expression of proinflammatory cytokines in mast cells. Archives of Pharmacal Research, 31(10), 1303-1311.

Parys, M., Yuzbasiyan-Gurkan, V., \& Kruger, J. M. (2018). Serum cytokine profiling in cats with acute idiopathic cystitis. Journal of Veterinary Internal Medicine, 32(1), 274-279.

Platt, J. F., Ellis, J. H., Rubin, J. M., DiPietro, M. A., \& Sedman, A. B. (1990). Intrarenal arterial Doppler sonography in patients with nonobstructive renal disease: Correlation of resistive index with biopsy findings. American Journal of Roentgenology, 154(6), 1223-1227.

Pouchelon, J. L., Atkins, C. E., Bussadori, C., Oyama, M. A., Vaden, S. L., Bonagura, J. D., Chetboul, V., Cowgill, L. D., Elliot, J., Francey, T., Grauer, G. F., Fuentes, L. V., Moise, S. N., Polzin, D. J., Van Dongen, A. M., \& Van Israël, N. (2015). Cardiovascular-renal axis disorders in the domestic dog and cat: A veterinary consensus statement. Journal of Small Animal Practice, 56(9), 537-552.

Semyonov, A., Shulzhenko, N., \& Danylenko, V. (2015). Efektyvnist preparatu uro-vaksom za hostroho urotsystytu u kotiv [Efficacy of the medicine UroVaksom for acute urocystitis in cats]. Science and Technology Bulletin of SRC for Biosafety and Environmental Control of AIC, 4(3), 46-51 (in Ukrainian).

Shulzhenko, N. N., \& Ryabik, A. P. (2017). Efektyvnist kompleksnoho likuvannia u sobak za hepatorenalnoho syndromu [Efficiency of complex treatment of hepatorenal syndrome in dogs]. Science and Technology Bulletin of SRC for Biosafety and Environmental Control of AIC, 5(1), 37-41 (in Ukrainian).

Weese, J. S., Blondeau, J. M., Boothe, D., Breitschwerdt, E. B., Guardabassi, L., Hillier, A., Lloyd, D. H., Papich, M. G., Rankin, S. C., Turnidge, J. D., \& Sykes, J. E. (2011). Antimicrobial use guidelines for treatment of urinary tract disease in dogs and cats: Antimicrobial guidelines working group of the international society for companion animal infectious diseases. Veterinary Medicine International, 2011, ID 263768.

Wynn, S. G., \& Fougère, B. J. (2007). Veterinary herbal medicine. Elsevier, St. Louis, USA. 